九州大学学術情報リポジトリ

Kyushu University Institutional Repository

Effects of Irrigation and Nitrogen

Fertilization on Nitrogen Uptake and Nitrogen Use Efficiency of Wheat on a Clay Terrace Soil of Bangladesh

Rahman M., Ataur

MS student, Department of Soil Science, Bangabandhu Sheikh Mujibur Rahman Agricultura University

Karim, Sirajul A. J. M.

Solaiman R. M., A.

Department of Soil Science, Bangabandhu Sheikh Mujibur Rahman Agricultural University

Egashira, Kazuhiko

Laboratory of Soil Science, Division of Soil Science and Plant Production, Department of Plant Resources, Faculty of Agriculture, Kyushu University

https://doi.org/10.5109/24380

出版情報: 九州大学大学院農学研究院紀要. 45 (1)，pp. 309-316，2000-11. Kyushu University バージョン：

権利関係: 


\title{
Effects of Irrigation and Nitrogen Fertilization on Nitrogen Uptake and Nitrogen Use Efficiency of Wheat on a Clay Terrace Soil of Bangladesh
}

\author{
M. Ataur Rahman*, A. J. M. Sirajul Karim**, A. R. M. Solaiman** \\ and Kazuhiko Egashira***
}

\author{
Laboratory of Soil Science, Division of Soil Science and Plant Production, \\ Department of Plant Resources, Faculty of Agriculture, \\ Kyushu University, Fukuoka 812-8581, Japan \\ (Received June 1, 2000 and accepted August 18, 2000)
}

\begin{abstract}
A field research was conducted at the university farm of Bangabandhu Sheikh Mujibur Rahman Agricultural University, Bangladesh, during November 1997 to March 1998 in order to study the effects of irrigation and nitrogen fertilization on the uptake of nitrogen and nitrogen use efficiency of wheat. The experiment was executed in the split-plot design comprising the combination of the five levels of irrigation arranged as a main plot and the four rates of $\mathrm{N}$ application distributed to a sub-plot. The treatments for the study were the same as before. Both irrigation and $\mathrm{N}$ application have created a significant impact on $\mathrm{N}$ content, $\mathrm{N}$ uptake, and $\mathrm{N}$ use efficiency in wheat. The $\mathrm{N}$ content and $\mathrm{N}$ uptake of wheat were increased significantly by providing two to three irrigations having irrigation at the grain filling stage ( 80 days after sowing). Nitrogen application up to $120 \mathrm{~kg} \mathrm{ha}^{-1}$ also increased the $\mathrm{N}$ content and $\mathrm{N}$ uptake of wheat. The $\mathrm{N}$ content in wheat grain was found to be highly correlated with the leaf $\mathrm{N}$ content at the different growth stages. A negative relationship existed between $\mathrm{N}$ use efficiency of wheat and the rate of $\mathrm{N}$ application.
\end{abstract}

\section{INTRODUCTION}

Efficient $\mathrm{N}$ uptake and assimilation are essential for the optimum growth and yield of wheat. Grain protein content correlated with grain $\mathrm{N}$ content is of considerable economic importance. Increased $\mathrm{N}$ accumulation generally results in the increased grain protein yield. Field and green house studies have shown that $\mathrm{N}$ uptake by wheat plant contributes significantly to build-up of grain N (Cooper and Blankeney, 1990; Dhugga and Waines, 1989). Nitrogen uptake and its assimilation in wheat are governed by various agronomic factors. Soil water and $\mathrm{N}$ are the two important factors contributing $\mathrm{N}$ uptake and grain $\mathrm{N}$ yield. Favourable soil water conditions during the growing season are required for the high grain yield and for the positive yield response to $\mathrm{N}$ fertilization (Rasmussen and Rohde, 1991). When soil water and $\mathrm{N}$ are adequate for wheat, high grain $\mathrm{N}$ yield is also achieved (Johnston and Flowler, 1991). In contrast, inadequate soil water during the growing season results in the reduced $\mathrm{N}$ accumulation and $\mathrm{N}$ use efficiency

* MS student, Department of Soil Science, Bangabandhu Sheikh Mujibur Rahman Agricultural University, Salna, Gazipur 1703, Bangladesh; currently serving at Wheat Research Center, Noshipur, Dinajpur, Bangladesh

** Department of Soil Science, Bangabandhu Sheikh Mujibur Rahman Agricultural University, Salna, Gazipur 1703, Bangladesh

*** Corresponding author (E-mail: kegashi@agr.kyushu-u.ac.jp) 
(NUE) of wheat. Excess watering increases the potential for ground water pollution from soil nitrates. Thus watering at right time with right amount is important to increase $\mathrm{N}$ accumulation and NUE of wheat.

In wheat and many other crops, high correlation between the amount of applied $\mathrm{N}$ and the leaf $\mathrm{N}$ content has been reported under the controlled condition. Due to unpredictable influence of climatic and soil conditions, there are some differences among the results related to $\mathrm{N}$ content, $\mathrm{N}$ uptake and NUE of wheat as influenced by applied $\mathrm{N}$ in the field condition. With increase in applied $\mathrm{N}$ fertilizer, agronomic efficiency usually declines (Doyle and Holford, 1993). Much work has been done on rice to explore potential $\mathrm{N}$ uptake and utilization efficiency of applied $\mathrm{N}$ through agronomic management but little effort has been made for wheat. The present study was carried out to examine the effects of irrigation and $\mathrm{N}$ fertilization on $\mathrm{N}$ uptake and NUE of wheat on a clay terrace soil of Bangladesh. This is the third part of the study on wheat production, following the previous papers (Rahman et al., 2000a, b).

\section{MATERIALS AND METHODS}

The experiment was conducted at the research farm of Bangabandhu Sheikh Mujibur Rahman Agricultural University (BSMRAU), Gazipur, Bangladesh during November 1997 to March 1998. The soil, climate, test crop, experimental design, fertilizer application, sowing of seeds, and cultural operations of the experiment, and statistical analysis were mentioned in the previous paper (Rahman et al., 2000a). Sampling of wheat plant was also uescribed in the previous paper (Rahman et al., 2000a). The above-ground plant-parts were segmented into different components and then dried in an oven at $70^{\circ} \mathrm{C}$ for $72 \mathrm{hr}$ followed by weighing. Plant and soil $\mathrm{N}$ was determined by the Kjeldahl method.

\section{Nitrogen uptake by plants}

Nitrogen uptake by leaves was calculated from weight of leaves $\left(\mathrm{kg} \mathrm{ha}^{-1}\right)$ and the leaf $\mathrm{N}$ content. Similarly, straw and grain N uptakes were calculated by their weights with respective $\mathrm{N}$ contents. Total $\mathrm{N}$ uptake by wheat is the summation of $\mathrm{N}$ uptake by straw and grain.

\section{Nitrogen use efficiency}

Nitrogen use efficiency was calculated as the ratio of grain yield $\left(\mathrm{kg} \mathrm{ha}^{-1}\right)$ to total $\mathrm{N}$ uptake $\left(\mathrm{kg} \mathrm{ha}^{-1}\right)$ by wheat for a particular treatment.

\section{Residual soil nitrogen}

After the harvest soil samples up to a depth of $20 \mathrm{~cm}$ at two equal splits $(0-10$ and $10-20 \mathrm{~cm}$ ) were collected from each plot and total $\mathrm{N}$ was determined.

\section{RESULTS AND DISCUSSION}

\section{Nitrogen content and uptake of leaves}

The effects of irrigation and $\mathrm{N}$ application on the leaf $\mathrm{N}$ content and $\mathrm{N}$ uptake by leaves are presented in Tables 1 and 2 , respectively. Since all the irrigation treatments 
Table 1. Effect of irrigation on leaf $\mathrm{N}$ content and $\mathrm{N}$ uptake by leaves at the maturity stage (104 DAS) of wheat.

\begin{tabular}{ccc}
\hline Treatment & N content $(\%)$ & N uptake $\left(\mathrm{kg} \mathrm{ha}^{-1}\right)$ \\
\hline $\mathrm{I}_{0}$ & $0.97 \mathrm{c}$ & $14.26 \mathrm{c}$ \\
$\mathrm{I}_{1}$ & $1.12 \mathrm{~b}$ & $17.84 \mathrm{~b}$ \\
$\mathrm{I}_{2}$ & $1.12 \mathrm{~b}$ & $18.14 \mathrm{~b}$ \\
$\mathrm{I}_{3}$ & $1.46 \mathrm{a}$ & $27.26 \mathrm{a}$ \\
$\mathrm{I}_{4}$ & $1.41 \mathrm{a}$ & $25.88 \mathrm{a}$ \\
\hline
\end{tabular}

Treatments having a common letter in column are not significantly different at $5 \%$ level.

Table 2. Effect of $\mathrm{N}$ application on leaf $\mathrm{N}$ content and $\mathrm{N}$ uptake by leaves at different growth stages of wheat.

\begin{tabular}{|c|c|c|c|c|c|c|}
\hline \multirow[b]{2}{*}{ Treatment } & \multicolumn{3}{|c|}{$\mathrm{N}$ content $(\%)$} & \multicolumn{3}{|c|}{$\mathrm{N}$ uptake ( $\left.\mathrm{kg} \mathrm{ha}^{-1}\right)$} \\
\hline & $\begin{array}{l}\text { Booting } \\
\text { (60DAS) }\end{array}$ & $\begin{array}{l}\text { Anthesis } \\
\text { (70 DAS) }\end{array}$ & $\begin{array}{l}\text { Maturity } \\
\text { (104 DAS) }\end{array}$ & $\begin{array}{l}\text { Booting } \\
\text { (60 DAS) }\end{array}$ & $\begin{array}{l}\text { Anthesis } \\
\text { (70DAS) }\end{array}$ & $\begin{array}{c}\text { Maturity } \\
\text { (104 DAS) }\end{array}$ \\
\hline $\mathrm{N}_{0}$ & $2.56 \mathrm{~d}$ & $1.75 \mathrm{~d}$ & $0.45 \mathrm{~d}$ & $18.98 \mathrm{~d}$ & $12.37 \mathrm{~d}$ & $2.83 \mathrm{~d}$ \\
\hline $\mathrm{N}_{1}$ & $3.12 \mathrm{c}$ & $2.66 \mathrm{c}$ & $0.96 \mathrm{c}$ & $56.79 \mathrm{c}$ & $43.86 \mathrm{c}$ & $14.90 \mathrm{c}$ \\
\hline $\mathrm{N}_{2}$ & $3.57 \mathrm{~b}$ & $3.54 \mathrm{~b}$ & $1.40 \mathrm{~b}$ & $81.01 \mathrm{~b}$ & $70.37 \mathrm{~b}$ & $26.86 \mathrm{~b}$ \\
\hline $\mathrm{N}_{3}$ & $3.92 \mathrm{a}$ & $4.00 \mathrm{a}$ & $2.01 \mathrm{a}$ & $89.80 \mathrm{a}$ & $79.37 \mathrm{a}$ & $38.12 \mathrm{a}$ \\
\hline
\end{tabular}

Treatments having a common letter in column are not significantly different at $5 \%$ level.

could not be completed before the grain filling stage ( $80 \mathrm{DAS}$ ) of wheat, leaf $\mathrm{N}$ content and $\mathrm{N}$ uptake for irrigation treatment were determined only at the maturity stage (104 DAS). Irrigation has created a significant impact on the leaf $\mathrm{N}$ content and $\mathrm{N}$ uptake by leaves (Table 1). The treatment which included irrigation at the grain filling stage (80 DAS) $\left(\mathrm{I}_{3}\right.$ and $\mathrm{I}_{4}$ ) exhibited the significantly higher leaf $\mathrm{N}$ content and $\mathrm{N}$ uptake by leaves. Amin (1997) found higher total $\mathrm{N}$ in all parts of wheat plant under higher frequency of irrigation.

Leaf $\mathrm{N}$ content and $\mathrm{N}$ uptake were determined at the booting (60DAS), anthesis (70 DAS) and maturity (104 DAS) stages of wheat in the study of $\mathrm{N}$ application effect (Table 2). The effect of $\mathrm{N}$ application on the leaf $\mathrm{N}$ content and $\mathrm{N}$ uptake was significant. The leaf $\mathrm{N}$ content increased linearly with every increase in applied $\mathrm{N}$. Plants receiving $\mathrm{N}$ at the rate of $160 \mathrm{~kg} \mathrm{ha}^{-1}\left(\mathrm{~N}_{3}\right)$ had the significantly highest leaf $\mathrm{N}$ content at all the growth stages. Nitrogen uptake by leaves was also significantly higher under higher dose of $\mathrm{N}$. The results are supported by the findings of Johnston and Flowler (1991), who reported that tissue $\mathrm{N}$ content and $\mathrm{N}$ yield increased with the increasing rate of $\mathrm{N}$ application. The leaf $\mathrm{N}$ content varied considerably with growth stages of wheat, being highest at booting and minimum at maturation. The reduction of leaf $\mathrm{N}$ content from the booting to maturity stages might be due to translocation of $\mathrm{N}$ from leaves to reproductive organs or grains.

\section{Nitrogen content and uptake of grains}

Grain $\mathrm{N}$ content is considered to be an index of grain quality and protein content. It 
was felt important to assess the effects of irrigation and $\mathrm{N}$ application on the $\mathrm{N}$ content of grains. The main effect of $\mathrm{N}$ application as well as the interaction effect of irrigation and $\mathrm{N}$ application on the $\mathrm{N}$ content of grains was significant (Table 3). The highest average grain $\mathrm{N}$ content (2.44\%) was found under application of $\mathrm{N}$ at the rate of $120 \mathrm{~kg} \mathrm{ha}^{-1}\left(\mathrm{~N}_{2}\right)$ that was statistically similar to the content at $160 \mathrm{~kg} \mathrm{~N}^{-1}\left(\mathrm{~N}_{3}\right)$ but different from the contents of other $\mathrm{N}$ treatments. It indicates that the grain $\mathrm{N}$ content increases with applied fertilizer $\mathrm{N}$ up to a certain limit. The result is similar to the findings of Karczmarczyk et al. (1993) and Johnston and Flowler (1991). The content of grain N was found to be closely related to the content of leaf $\mathrm{N}$ in factors of nitrogen and interaction (Table 4). The correlation between grain and leaf $\mathrm{N}$ contents indicates that the treatments which showed the higher leaf $\mathrm{N}$ content at different growth stages have produced the higher grain $\mathrm{N}$ content. The results are in agreement with the findings of Waldren and Flowerday (1979), who reported that about two-thirds of leaf $\mathrm{N}$ were translocated to grains. The response to irrigation was interrupted by rain at the early growth stage of wheat plant (Rahman et al., 2000a). This may be the reason of non-response of the grain $\mathrm{N}$ content to irrigation treatment (Table 3 ).

Nitrogen uptake by wheat grains was significantly influenced by irrigation and $\mathrm{N}$ application (Table 5) and found to be highly correlated with $\mathrm{N}$ uptake by leaves at different growth stages (Table 6). The treatments which included irrigation at the grain filling stage (80DAS) $\left(\mathrm{I}_{3}\right.$ and $\left.\mathrm{I}_{4}\right)$ showed the significantly higher uptake of $\mathrm{N}$ by grains.

Table 3. Interaction effect of irrigation and $\mathrm{N}$ application on $\mathrm{N}$ content of wheat grains (\%).

\begin{tabular}{cllcccc}
\hline Treatment & \multicolumn{1}{c}{$\mathrm{I}_{0}$} & \multicolumn{1}{c}{$\mathrm{I}_{1}$} & \multicolumn{1}{c}{$\mathrm{I}_{2}$} & \multicolumn{1}{c}{$\mathrm{I}_{3}$} & \multicolumn{1}{c}{$\mathrm{I}_{4}$} & Mean \\
\hline $\mathrm{N}_{0}$ & $2.06 \mathrm{C} \mathrm{a}$ & $2.10 \mathrm{C} \mathrm{a}$ & $2.06 \mathrm{C} \mathrm{a}$ & $2.06 \mathrm{C} \mathrm{a}$ & $2.00 \mathrm{C} \mathrm{a}$ & $2.05 \mathrm{C}$ \\
$\mathrm{N}_{1}$ & $2.33 \mathrm{~B} \mathrm{a}$ & $2.15 \mathrm{BC} \mathrm{b}$ & $2.24 \mathrm{~B} \mathrm{ab}$ & $2.24 \mathrm{~B} \mathrm{ab}$ & $2.32 \mathrm{~B} \mathrm{a}$ & $2.26 \mathrm{~B}$ \\
$\mathrm{~N}_{2}$ & $2.43 \mathrm{~A} \mathrm{ab}$ & $2.38 \mathrm{AB} \mathrm{b}$ & $2.38 \mathrm{AB} \mathrm{b}$ & $2.47 \mathrm{~A} \mathrm{ab}$ & $2.53 \mathrm{~A} \mathrm{a}$ & $2.44 \mathrm{~A}$ \\
$\mathrm{~N}_{3}$ & $2.37 \mathrm{AB} \mathrm{b}$ & $2.45 \mathrm{~A} \mathrm{a}$ & $2.44 \mathrm{~A} \mathrm{a}$ & $2.39 \mathrm{~A} \mathrm{~b}$ & $2.49 \mathrm{~A} \mathrm{a}$ & $2.43 \mathrm{~A}$ \\
Mean & $2.30 \mathrm{a}$ & $2.27 \mathrm{a}$ & $2.28 \mathrm{a}$ & $2.30 \mathrm{a}$ & $2.34 \mathrm{a}$ & 2.30 \\
\hline
\end{tabular}

Treatments having a common capital letter in column and those having a common small letter in row are not significantly different at $5 \%$ level.

Table 4. Correlation coefficients between grain and leaf $\mathrm{N}$ contents at different growth stages of wheat as influenced by irrigation, $\mathrm{N}$ application, and their interaction.

\begin{tabular}{lccc}
\hline \multirow{2}{*}{ Factor } & \multicolumn{3}{c}{ Growth stage } \\
\cline { 2 - 4 } & $\begin{array}{c}\text { Vegetative } \\
\text { (45DAS) }\end{array}$ & $\begin{array}{c}\text { Anthesis } \\
(75 \text { DAS })\end{array}$ & $\begin{array}{c}\text { Maturity } \\
\text { (104DAS) }\end{array}$ \\
\hline Irrigation $(\mathrm{n}=5)$ & $\mathrm{Nd}$ & $\mathrm{Nd}$ & 0.558 \\
Nitrogen $(\mathrm{n}=4)$ & 0.962 & 0.974 & 0.910 \\
Interaction $(\mathrm{n}=20)$ & $\mathrm{Nd}$ & $\mathrm{Nd}$ & 0.827 \\
\hline
\end{tabular}

Nd: not determined. 
Table 5. Interaction effect of irrigation and $\mathrm{N}$ application on $\mathrm{N}$ uptake by wheat grains $\left(\mathrm{kg} \mathrm{ha}^{1}\right)$.

\begin{tabular}{ccccccc}
\hline Treatment & $\mathrm{I}_{0}$ & \multicolumn{1}{c}{$\mathrm{I}_{1}$} & \multicolumn{1}{c}{$\mathrm{I}_{2}$} & $\mathrm{I}_{3}$ & $\mathrm{I}_{4}$ & Mean \\
\hline $\mathrm{N}_{0}$ & $18.4 \mathrm{~B} \mathrm{C}$ & $20.7 \mathrm{C} \mathrm{a}$ & $23.2 \mathrm{C} \mathrm{a}$ & $26.1 \mathrm{C} \mathrm{a}$ & $24.0 \mathrm{C} \mathrm{a}$ & $22.5 \mathrm{C}$ \\
$\mathrm{N}_{1}$ & $76.1 \mathrm{~A} \mathrm{a}$ & $73.0 \mathrm{~B} \mathrm{a}$ & $75.5 \mathrm{~B} \mathrm{a}$ & $77.5 \mathrm{~B} \mathrm{a}$ & $80.1 \mathrm{~B} \mathrm{a}$ & $76.4 \mathrm{~B}$ \\
$\mathrm{~N}_{2}$ & $82.8 \mathrm{Ab}$ & $80.5 \mathrm{Ab}$ & $87.4 \mathrm{~A} \mathrm{~b}$ & $99.3 \mathrm{~A} \mathrm{a}$ & $108.6 \mathrm{~A} \mathrm{a}$ & $91.7 \mathrm{~A}$ \\
$\mathrm{~N}_{3}$ & $77.3 \mathrm{~A} \mathrm{C}$ & $87.2 \mathrm{Ab}$ & $87.2 \mathrm{Ab}$ & $93.3 \mathrm{~A} \mathrm{ab}$ & $101.8 \mathrm{~A} \mathrm{a}$ & $89.4 \mathrm{~A}$ \\
Mean & $63.7 \mathrm{~b}$ & $65.4 \mathrm{~b}$ & $68.3 \mathrm{~b}$ & $74.0 \mathrm{a}$ & $78.6 \mathrm{a}$ & 70.0 \\
\hline
\end{tabular}

Treatments having a common capital letter in column and those having a common small letter in row are not significantly different at $5 \%$ level.

Table 6. Correlation coefficients between grain and leaf $\mathrm{N}$ uptakes at different growth stages of wheat as influenced by irrigation, $\mathrm{N}$ application, and their interaction.

\begin{tabular}{lccc}
\hline \multirow{2}{*}{ Factor } & \multicolumn{3}{c}{ Growth stages } \\
\cline { 2 - 4 } & $\begin{array}{c}\text { Vegetative } \\
(45 \mathrm{DAS})\end{array}$ & $\begin{array}{c}\text { Anthesis } \\
(75 \mathrm{DAS})\end{array}$ & $\begin{array}{c}\text { Maturity } \\
(104 \mathrm{DAS})\end{array}$ \\
\hline Irrigation $(\mathrm{n}=5)$ & $\mathrm{Nd}$ & $\mathrm{Nd}$ & 0.925 \\
Nitrogen $(\mathrm{n}=4)$ & 0.962 & 0.943 & 0.868 \\
Interaction $(\mathrm{n}=20)$ & $\mathrm{Nd}$ & $\mathrm{Nd}$ & 0.840 \\
\hline
\end{tabular}

$\mathrm{Nd}$ : not determined.

Nitrogen uptake by grains increased with the increasing rate of $\mathrm{N}$ application up to $120 \mathrm{~kg}$ $\mathrm{ha}^{-1}\left(\mathrm{~N}_{2}\right)$. Doyle and Holford (1993) reported that $\mathrm{N}$ uptake increased with increasing the amount of $\mathrm{N}$ fertilizer. The highest grain $\mathrm{N}$ uptake $\left(108.6 \mathrm{~kg} \mathrm{ha}^{-1}\right)$ was recorded in $\mathrm{I}_{4} \mathrm{~N}_{2}$ which was statistically similar to $\mathrm{I}_{4} \mathrm{~N}_{3}, \mathrm{I}_{3} \mathrm{~N}_{2}$ and $\mathrm{I}_{3} \mathrm{~N}_{3}$.

\section{Nitrogen content and uptake of straw at harvest and total nitrogen uptake}

The effects of irrigation and $\mathrm{N}$ application on the $\mathrm{N}$ content and $\mathrm{N}$ uptake of wheat straw at harvest were significant (Tables 7 and 8). The highest average straw $\mathrm{N}$ content $(0.73 \%)$ was recorded in $I_{3}$. There was no significant variation among $I_{3}, I_{1}$ and $I_{4}$ in this respect. Significantly higher $\mathrm{N}$ uptake by straw as well as total $\mathrm{N}$ uptake by wheat plant was noted in the treatments where irrigation was provided at the grain filling stage (80 DAS) $\left(\mathrm{I}_{3}\right.$ and $\left.\mathrm{I}_{4}\right)$. Increment of $\mathrm{N}$ dose has led to increase in the $\mathrm{N}$ content and $\mathrm{N}$ uptake of straw (Table 8). Similar trend was found in case of total $\mathrm{N}$ uptake by wheat plant. The results are supported by the findings of Sharma et al. (1991), who reported that increasing irrigation frequency and $\mathrm{N}$ application rate increased $\mathrm{N}$ uptake by wheat plant.

The interaction effect of irrigation and $\mathrm{N}$ application on the total $\mathrm{N}$ uptake by wheat plant was significant (Table 9). Total $\mathrm{N}$ uptake increased with the increasing level of irrigation and $\mathrm{N}$ application up to a certain extent. The highest total $\mathrm{N}$ uptake $(170.4 \mathrm{~kg}$ ha-1) was found in $\mathrm{I}_{4} \mathrm{~N}_{2}$ which was statistically similar to $\mathrm{I}_{4} \mathrm{~N}_{3}, \mathrm{I}_{3} \mathrm{~N}_{2}$ and $\mathrm{I}_{3} \mathrm{~N}_{3}$. Charanjeet and Das (1985) also reported that $\mathrm{N}$ uptake increased with both applied $\mathrm{N}$ and irrigation. 
Table 7. Effect of irrigation on $\mathrm{N}$ content and uptake of straw at harvest, total $\mathrm{N}$ uptake, and $\mathrm{N}$ use efficiency.

\begin{tabular}{ccccc}
\hline \multirow{2}{*}{ Treatment } & \multicolumn{2}{c}{$\mathrm{N}$ in straw at harvest } & $\begin{array}{c}\text { Total N uptake } \\
\left(\mathrm{kg} \mathrm{ha}^{-1}\right)\end{array}$ & $\begin{array}{c}\text { N use efficiency (kg } \\
\text { grain kg } \mathrm{N}^{-1} \text { uptake) }\end{array}$ \\
\cline { 2 - 3 } & Content (\%) & Uptake $\left(\mathrm{kg} \mathrm{ha}^{-1}\right)$ & $96.6 \mathrm{~b}$ & $31.8 \mathrm{a}$ \\
$\mathrm{I}_{0}$ & $0.65 \mathrm{bc}$ & $32.9 \mathrm{c}$ & $103.5 \mathrm{~b}$ & $31.2 \mathrm{a}$ \\
$\mathrm{I}_{1}$ & $0.69 \mathrm{ab}$ & $38.1 \mathrm{~b}$ & $104.4 \mathrm{~b}$ & $33.1 \mathrm{a}$ \\
$\mathrm{I}_{2}$ & $0.63 \mathrm{c}$ & $36.1 \mathrm{~b}$ & $117.6 \mathrm{a}$ & $32.4 \mathrm{a}$ \\
$\mathrm{I}_{3}$ & $0.73 \mathrm{a}$ & $43.6 \mathrm{a}$ & $121.3 \mathrm{a}$ & $32.0 \mathrm{a}$ \\
$\mathrm{I}_{4}$ & $0.67 \mathrm{ab}$ & $42.7 \mathrm{a}$ &
\end{tabular}

Treatments having a common letter in column are not significantly different at $5 \%$ level.

Table 8. Effect of $N$ application on $N$ content and uptake of straw at harvest, total $N$ uptake, and $\mathrm{N}$ use efficiency.

\begin{tabular}{|c|c|c|c|c|}
\hline \multirow{2}{*}{ Treatment } & \multicolumn{2}{|c|}{$\mathrm{N}$ in straw at harvest } & \multirow{2}{*}{$\begin{array}{l}\text { Total N uptake } \\
\qquad\left(\mathrm{kg} \mathrm{ha}^{-1}\right)\end{array}$} & \multirow{2}{*}{$\begin{array}{l}\text { Nuse efficiency (kg } \\
\text { grain kg-1 } \mathrm{N} \text { uptake) }\end{array}$} \\
\hline & Content (\%) & Uptake $\left(\mathrm{kg} \mathrm{ha}^{-1}\right)$ & & \\
\hline $\mathrm{N}_{0}$ & $0.34 \mathrm{~d}$ & $7.8 \mathrm{~d}$ & $30.3 \mathrm{c}$ & $35.8 \mathrm{a}$ \\
\hline$N_{1}$ & $0.64 \mathrm{c}$ & $36.6 \mathrm{c}$ & $113.0 \mathrm{~b}$ & $34.4 \mathrm{a}$ \\
\hline $\mathrm{N}_{2}$ & $0.83 \mathrm{~b}$ & $53.2 \mathrm{~b}$ & $144.9 \mathrm{a}$ & $30.0 \mathrm{~b}$ \\
\hline $\mathrm{N}_{3}$ & $0.90 \mathrm{a}$ & $57.7 \mathrm{a}$ & $147.1 \mathrm{a}$ & $28.2 \mathrm{~b}$ \\
\hline
\end{tabular}

Treatments having a common letter in column are not significantly different at $5 \%$ level.

Table 9. Interaction effect of irrigation and $\mathrm{N}$ application on total $\mathrm{N}$ uptake by wheat plant $\left(\mathrm{kg} \mathrm{ha}^{\mathrm{s}}\right)$.

\begin{tabular}{crrrrrr}
\hline Treatment & \multicolumn{1}{c}{$\mathrm{I}_{0}$} & \multicolumn{1}{c}{$\mathrm{I}_{1}$} & \multicolumn{1}{c}{$\mathrm{I}_{2}$} & \multicolumn{1}{c}{$\mathrm{I}_{3}$} & \multicolumn{1}{c}{$\mathrm{I}_{4}$} & \multicolumn{1}{c}{ Mean } \\
\hline $\mathrm{N}_{3}$ & $23.7 \mathrm{C} \mathrm{b}$ & $28.9 \mathrm{D} \mathrm{ab}$ & $31.0 \mathrm{C} \mathrm{ab}$ & $35.7 \mathrm{C} \mathrm{a}$ & $32.1 \mathrm{C} \mathrm{ab}$ & $30.3 \mathrm{C}$ \\
$\mathrm{N}_{1}$ & $111.3 \mathrm{~B} \mathrm{a}$ & $111.5 \mathrm{C} \mathrm{a}$ & $107.9 \mathrm{~B} \mathrm{a}$ & $118.9 \mathrm{~B} \mathrm{a}$ & $115.3 \mathrm{~B} \mathrm{a}$ & $112.9 \mathrm{~B}$ \\
$\mathrm{~N}_{2}$ & $128.9 \mathrm{~A} \mathrm{~b}$ & $130.5 \mathrm{~B} \mathrm{~b}$ & $135.8 \mathrm{Ab}$ & $159.1 \mathrm{~A} \mathrm{a}$ & $170.4 \mathrm{~A} \mathrm{a}$ & $144.9 \mathrm{~A}$ \\
$\mathrm{~N}_{3}$ & $122.4 \mathrm{~A} \mathrm{C}$ & $146.2 \mathrm{~A} \mathrm{~b}$ & $142.8 \mathrm{Ab}$ & $156.8 \mathrm{~A} \mathrm{a}$ & $167.3 \mathrm{~A} \mathrm{a}$ & $147.1 \mathrm{~A}$ \\
Mean & $96.6 \mathrm{~b}$ & $104.3 \mathrm{~b}$ & $104.4 \mathrm{~b}$ & $117.6 \mathrm{a}$ & $121.3 \mathrm{a}$ & 108.8 \\
\hline
\end{tabular}

Treatments having a common capital letter in column and those having a common small letter in row are not significantly different at $5 \%$ level.

From the above results it may be concluded that irrigation at the grain filling stage together with the application of higher rate of $\mathrm{N}$ (preferably $120 \mathrm{~kg} \mathrm{ha}^{-1}$ ) favours $\mathrm{N}$ uptake by wheat on a clay terrace soil of Bangladesh.

\section{Nitrogen use efficiency}

There was no significant impact of irrigation treatment on NUE of wheat (Table 7). However, it varied significantly with $\mathrm{N}$ treatment, and a negative relationship between NUE and the rate of $\mathrm{N}$ application was observed (Table 8). Significantly higher values of 
34.4 and $35.8 \mathrm{~kg}$ grain $\mathrm{kg}^{-1} \mathrm{~N}$ uptake were recorded under minimum $\left(\mathrm{N}_{1}\right)$ and no application $\left(\mathrm{N}_{0}\right)$ of $\mathrm{N}$. The reduced values of $\mathrm{NUE}$ at higher $\mathrm{N}$ doses indicate that grain yield of wheat did not increase proportionately with increased $\mathrm{N}$ uptake. The result is similar to the findings of Sharma et al. (1990), who reported that NUE of wheat was highest with $60 \mathrm{~kg} \mathrm{~N} \mathrm{ha}^{-1}$ and decreased with further increase in the $\mathrm{N}$ application rate irrespective of irrigation regimes. The reduction of NUE with increasing the amount of $\mathrm{N}$ fertilizer was also reported by Doyle and Holford (1993) and Gauer et al. (1992).

\section{Residual soil nitrogen}

Residual $\mathrm{N}$ of the surface layer $(0-10 \mathrm{~cm})$ was found to be influenced by both irrigation and $\mathrm{N}$ application (Table 10), but there was no significant impact of irrigation on residual $\mathrm{N}$ of the subsurface layer $(10-20 \mathrm{~cm}$ ) (Table 11 ). The least average soil $\mathrm{N}$ in the surface layer $(0.06 \%)$ was noted in non-irrigated plot $\left(\mathrm{I}_{0}\right)$ while the highest value $(0.08 \%)$ being observed under the highest frequency of irrigation $\left(\mathrm{I}_{4}\right)$. Higher volatilization loss of $\mathrm{N}$ from drier soil might have reduced the $\mathrm{N}$ content in non-irrigated

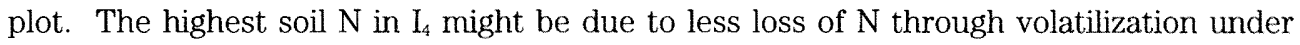
higher frequency of irrigation and the treatment allowed irrigation up to field capacity did not permit percolation loss of $\mathrm{N}$.

In general, residual soil $\mathrm{N}$ was found to be increased with the increasing rate of $\mathrm{N}$ application (Tables 10 and 11). The highest average soil residual $\mathrm{N}(0.08 \%$ in the surface

Table 10. Effects of irrigation and $\mathrm{N}$ application on total residual $\mathrm{N}$ in the surface layer $(0-10 \mathrm{~cm})$ after harvest of wheat $(\%)$.

\begin{tabular}{ccccccc}
\hline Treatment & $\mathrm{I}_{0}$ & $\mathrm{I}_{1}$ & $\mathrm{I}_{2}$ & $\mathrm{I}_{3}$ & $\mathrm{I}_{4}$ & Mean \\
\hline $\mathrm{N}_{0}$ & 0.04 & 0.05 & 0.05 & 0.05 & 0.05 & $0.05 \mathrm{C}$ \\
$\mathrm{N}_{1}$ & 0.07 & 0.08 & 0.07 & 0.08 & 0.07 & $0.07 \mathrm{~B}$ \\
$\mathrm{~N}_{2}$ & 0.07 & 0.09 & 0.08 & 0.09 & 0.09 & $0.08 \mathrm{~A}$ \\
$\mathrm{~N}_{3}$ & 0.07 & 0.08 & 0.08 & 0.09 & 0.09 & $0.08 \mathrm{~A}$ \\
Mean & $0.06 \mathrm{c}$ & $0.07 \mathrm{~b}$ & $0.07 \mathrm{~b}$ & $0.07 \mathrm{~b}$ & $0.08 \mathrm{a}$ & 0.07 \\
\hline
\end{tabular}

Treatments having a common capital letter in column and those having a common small letter in row are not significantly different at $5 \%$ level.

Table 11. Effects of irrigation and $\mathrm{N}$ application on total residual $\mathrm{N}$ in the subsurface layer $(10 \cdots 20 \mathrm{~cm})$ after harvest of wheat (\%).

\begin{tabular}{ccccccc}
\hline Treatment & $\mathrm{I}_{0}$ & $\mathrm{I}_{1}$ & $\mathrm{I}_{2}$ & $\mathrm{I}_{3}$ & $\mathrm{I}_{4}$ & Mean \\
\hline $\mathrm{N}_{0}$ & 0.02 & 0.03 & 0.03 & 0.02 & 0.03 & $0.03 \mathrm{C}$ \\
$\mathrm{N}_{1}$ & 0.04 & 0.04 & 0.05 & 0.06 & 0.05 & $0.05 \mathrm{~B}$ \\
$\mathrm{~N}_{3}$ & 0.05 & 0.05 & 0.05 & 0.05 & 0.05 & $0.05 \mathrm{~B}$ \\
$\mathrm{~N}_{3}$ & 0.06 & 0.06 & 0.05 & 0.07 & 0.06 & $0.06 \mathrm{~A}$ \\
Mean & $0.05 \mathrm{a}$ & $0.05 \mathrm{a}$ & $0.05 \mathrm{a}$ & $0.05 \mathrm{a}$ & $0.05 \mathrm{a}$ & 0.05 \\
\hline
\end{tabular}

Treatments having a common capital letter in column and those having a common small letter in row are not significantly different at $5 \%$ level. 
and $0.06 \%$ in the subsurface) was recorded under the highest level of $\mathrm{N}$ application in $\mathrm{N}_{3}$. Alcoz et al. (1993) and Sharma et al. (1991) reported that residual soil $\mathrm{NO}_{3}-\mathrm{N}$ was higher with the higher $\mathrm{N}$ application rate, similar to our observation.

\section{CONCLUSIONS}

From the experimental findings it may be concluded that the $\mathrm{N}$ content and $\mathrm{N}$ uptake in wheat increase with the inclusion of irrigation at the grain filling stage. Nitrogen application up to $120 \mathrm{~kg} \mathrm{ha}^{-1}$ also increases the $\mathrm{N}$ content and uptake of wheat. The $\mathrm{N}$ content in wheat grains is highly correlated with the leaf $\mathrm{N}$ content at different growth stages. A negative relationship exists between NUE of wheat and the rate of $\mathrm{N}$ application.

\section{REFERENCES}

Alcoz, M. M., F. M. Hons and V. A. Haby 1993 Nitrogen fertilization timing effect on wheat production, nitrogen uptake efficiency, and residual soil nitrogen. Agron. J., 85: 1198-1203

Amin. M 1997 Seed Bed Conditions, Sowing Depth, and Phosphorus Fertilizer Effect on Root Growth, Nutrient Uptake, and Yield of Wheat. Ph.D. thesis in Agronomy, BSMRAU, Salna, Gazipur, Bangladesh

Charanjeet, S. and D. K. Das 1985 Nitrate nitrogen distribution in soil and nitrogen uptake by wheat under varying levels of water and nitrogen supply. Annals of Agric. Res., 6: $92-97$

Cooper, J. L. and A. B. Blankeney 1990 The effects of two forms of nitrogen fertilizer applied near anthesis on the grain quality of irrigated wheat. Australian J. Exp. Agric., 30: 615-619

Dhugga, K. and J. G. Waines 1989 Analysis of nitrogen accumulation and use in bread and durum wheat. Crop Sci., 29: 1232-1239

Doyle, A. D. and I. C. R. Holford 1993 The uptake of nitrogen by wheat, its agronomic efficiency and their relationship to soil and fertilizer nitrogen. Australian J. Agric. Res., 44: 1245-1258

Gauer, L. E., C. A. Grant, D. T. Gehl and L. D. Bailey 1992 Effects of nitrogen fertilization on grain protein content, $\mathrm{N}$ uptake, and NUE of six spring wheat ( $T$. aestivum) culivars in relation to estimated moisture supply. Canadian J. Plant Sci., 72: 235-241

Johnston, A. M. and D. B. Flowler 1991 No-till winter wheat dry matter and tissue nitrogen response to nitrogen fertilizer form and placement. Agron. J., 83: 722-728

Karczmarczyk, S., F. Kozanska, D. Sciazco and M. Roy 1993 Courses of some photosynthetic processes and yield of winter wheat and triticale under the influence of sprinkler irrigation and nitrogen fertilizer application. Acta Agrobotanica, 46: 31-38

Rahman, M. A., A. J. M. S. Karim, M. M. Hoque and K. Egashira 2000a Effects of irrigation and nitrogen fertilization on photosynthesis, leaf area index and dry matter production of wheat on a clay terrace soil of Bangladesh. J. Fac. Agric., Kyushu Univ., 45: 309-316

Rahman, M. A., A. J. M. S. Karim, M. M. Hoque and K. Egashira 2000b Effects of irrigation and nitrogen fertilization on root growth and root characteistics of wheat on a clay terrace soil of Bangladesh. $J$. Fac. Agric., Kyushu Univ., 45: 309-316

Rasmussen, P. E. and C. R. Rohde 1991 Tillage, soil depth, and precipitation effects on wheat response to nitrogen. J. Soil Sci, 55: 121-124

Sharma, B. D., S. S. Cheema and S. Kar 1990 Water and nitrogen uptake of wheat as related to nitrogen application rate and irrigation water regime. Fertilizer News, 35: 31-35

Sharma, B. D., S. Kar and B. Singh 1991 Nitrate flux into root and uptake of nitrogen by wheat (Triticum aestivum) grown under different levels of nitrogen and irrigation. Indian J. Agric. Sci., 63: $465-470$

Waldren, R. P. and A. D. Flowerday 1979 Growth stages and distribution of dry matter, N, P, and K in winter wheat. Agron. J., 71: 391-397 